\title{
The Task of the College Library
}

William M. Randall is professor of library science in the Graduate Library School of the University of Chicago and managing editor of "The Library Quarterly."

$\mathrm{T}^{\mathrm{T}}$ Sometimes seems to me that we 1 would be much better off if we could rid our vocabulary of one word and its derivatives, and replace them with a series of terms which more accurately connote our institutions, our activities, and ourselves. The word I have in mind, of course, is "library," with its fellows, "librarianship" and "librarian." All of these are derived, in the end, from the Latin word for $b o o k$, and they originally referred-and still do in most languagesto bookselling and the book trade.

\section{Librarianship Has Different Meanings}

My dispute, however, is not with etymology. Words and their meanings and the changes in these meanings are beyond reason and logic, and certainly there is little value in arguing about them. Nothe cause of my unhappiness is quite different. My concern arises rather from the effect that words have upon the thinking and hence upon the actions of people. Because we call a group of institutions "libraries," we are likely to assume that all of the members of the group are the same sort of institutions. Because we give to a rather amorphous and undefinable lot of processes, techniques, judgments, and decisions the name "librarianship," we are likely to suppose that we have a single profession with a single necessary apprenticeship. And because we call all the members of the group concerned with these institutions and their management "librarians," it requires a real wrench of the imagination to realize that they are not all alike in their duties nor in the training necessary for the performance of them.

I will not say that I am a librarian. Perhaps that is stretching the word too far. The catalogers at the Library of Congress are all librarians. So are the people who work at the loan desk in Detroit and those who write the book orders at the University of Chicago. All of these are librarians. And all of them have an equal right to call what they are doing "librarianship."

The University of Michigan has a library; in fact, it has several libraries. They are not very much like one another except that all of them contain books. There is a public library in Chicago and there is a public library in the little town of Belleville, Michigan, but they are not very much alike, either. There is a library in Washington, D.C. devoted to works concerning Shakespeare and there is another library in the same city that serves the Department of Agriculture. I wonder if the number of their common problems is as great as the number of problems that are specific to each?

I do not believe that we can get the entire truth about the differences between the problems of various sorts of libraries 
from librarians. Membership in what is generally supposed to be a common profession and, above all, a common background of professional training that tends to enforce a common method for handling the stock-in-trade-books-inclines the personnel toward a common attitude. There are certain ways of doing things in libraries. Because these ways of doing things have been found to work pretty well in a single predominant type of institution, they are taught in library schools. If they do not work quite so well in other types of libraries, there seems to be an inclination on the part of the profession to put this failure down to some sort of contrariness on the part of the patrons, rather than to an unsuitableness of the method. The idea that two institutions that are both called libraries may nevertheless be entirely different in their character, their aims, their purposes, and hence should be entirely different in their methods and in the training necessary for their personnels, seems not to have taken a very strong hold on the imagination.

A person who is interested in history is likely to try to find an historical explanation for events. I believe there is something in the history of library science that goes some way toward explaining the situation in which we find ourselves.

\section{Dual Purpose of Modern Libraries}

Modern libraries have two great purposes: to collect and preserve knowledge in the form of books and other library materials and to interpret these books to a group of patrons in need of the knowledge which they contain. But this duality of purpose is a relatively recent development in library history. For many centuries the purpose of libraries was to collect and preserve, and as long as this remained the only purpose, the basis of the science of libraries was the thing collected and preserved-that is, the book. I do not mean to say that no one ever read the books in older libraries. But I do mean to say that the chief concern of the librarian was collection and preservation. We have only to remember the comparative newness of those techniques of librarianship, such as subject cataloging, which have as their purpose the interpretation of the contents of libraries to realize the truth of that statement.

\section{Books and Librarianship}

As long as you deal with books alone, and interest yourself only in their collection and preservation, you are dealing with things which are alike, and, since they are alike, with things which are amenable to a single technique. When we deal with books alone, and buildings to contain these books and keep them safe, and ways to arrange them in these buildings which depend only on the books themselves, and ways to enter them in catalogs which again depend only on the books themselves, we can have a single profession of librarianship. And that is what we have had for many years.

You may say that books themselves are different-different in their content, in their character, in their physical format. Of course they are. But for all those properties which enter into the business of collecting and preserving, books are not different in essential characteristics. What is true about a book in one library is true about it in another. A folio volume requires a special shelf in the Library of Congress or in the Peoria Public Library. The preservation of a vellum book presents the same problems in the Folger Library or the Library of the Department 
of Agriculture. The Huntington Library or the University of Illinois Library will find a given book best purchased from the same source. Steel stacks and air-conditioning are as useful one place as another. It required no particular wrench to introduce the Anglo-American theory of entry into the Vatican Library, because the theory of entry is based on books alone. The introduction of American subject cataloging was another thing.

So, a professional background is built up on a basis of a common element-the book. Convenient ways of collecting and preserving books are devised and studied and revised. We find ourselves suddenly with a profession built around this common element and a training for this profession which teaches people to do things to books. Sometimes it does not work so very well and we wonder why. Wellit is our own fault. If we would only stick to books, we should be all right.

\section{Book Interpretation and Librarianship}

As long as the only business of libraries is to acquire books and to keep them safe, librarianship has a common content which constitutes its larger part. The differences between libraries are very small compared to their likenesses. But as soon as the second function of the modern library is introduced-the function which may be described as book interpretationthe differences between libraries become greater in importance than their likenesses. The book, which before was the only unit about which the science was built, becomes only one of two units, and, furthermore, the one of lesser importance because it depends for its importance on the second unit. This other unit which must be considered in a modern library science is the patron.
Books which are alike in all respects as items for collection and preservation become quite different as items to be interpreted to readers. Even the same book becomes two different books in two different libraries, if they serve different groups. And when the books become different, the techniques which are suitable for their interpretation become different as well-or, at least, they may become different.

\section{Patron's Needs Should Determine Library Techniques}

As soon as we introduce the patron into the picture we are no longer able to say, for example, of a system of classification: "This is a good system because it arranges the books into classes which are exclusive, different, and logical." We must also be able to say, if we are to justify the system for a particular library, that it arranges the books into classes which have meaning for the patrons of the library. Unless it does this, the system is of no value to the patrons. We can no longer say of a list of subject headings: "This is a good list, because by means of its terms we can describe the content of the books." We must also be able to say that we can describe the content of the books in terms which the patron understands and in terms which are significant to him. Unless we can do this, our subject cataloging will be of doubtful usefulness. And it should be evident, I believe, that because a system of classification and a list of subject headings is found to be useful in a library of one type, serving one kind of patron, it is not necessarily true that it will therefore be useful in a library of another type, serving another kind of patron. In fact, logic will force us to conclude, it seems to me, that the more useful an interpretative technique 
is for one group, the more carefully it is fitted to the needs of one class of patrons seeking certain things from books, the less likely it is that it will serve satisfactorily to convey the necessary information about books to another group, who want to know something different about them and who are differently equipped by education and experience to find out what they want to know.

What is true of such things as classification and subject cataloging is equally true, of course, of other library techniques in which service to the patron is a factor. It is true of book selection. We cannot collect "good" books or "important" books or "significant" books. These terms have no meaning. We must select and acquire for a given library the books which are good and important and significant for the patrons of that library. We cannot even build "good" library buildings. The building, too, must be fitted to the needs of the group of patrons who are to be served by it.

\section{All Libraries Should Not Be Alike}

Now all patrons are not alike in what they need from libraries. It must follow, therefore, that all libraries should not be alike; and that all librarianship should not be the same; and that all librarians should not seek to do the same things in the same ways. We must realize this. We must study our professional training program carefully to identify the parts of it which are common to all types of librarians and should be taught to all. We must also study our professional training program carefully to identify the parts which are useful only to some and not only useless, but actually detrimental, to others.

The college library is in a class by itself when it is considered from the stand- point of its patrons. Its functions are well recognized. Further, they are dictated by the educational institution of which the library is a part. Its patrons form a homogeneous group. What they need from the library in the way of service is known, or can be discovered without much difficulty. Certainly they do not need the same sort of service as that required by the patron of a public library, or of the Library of Congress, or of an elementary school library, or even of a university library. There is no reason to suppose that a system of classification which suits a great national library-if it does-will suit a college library. There is no reason to suppose that a type of subject cataloging which serves the needs of public library patrons-if it does-or graduate students in a great university will also serve the needs of college students. We know-or we can find outfor what purposes college students use books. Why, then, should we not arrange, catalog, select, and administer the books in a college library definitely and accurately for these purposes?

As a matter of fact, we are forced to do just this in certain cases when the pressure is heavy. No matter what classification system we use; no matter what kind of cataloging we do; no matter how our reference service is organized, still, for the part of the book collection which is most used, we discard them all and arrange and administer the material as the college situation demands. In the case of reserve books, the college library is really a college library. It is not a public library or a university library or a reference library. But with all other books it becomes just a library, adopting for special purposes, for the use of a very special group of read-

(Continued on page 54) 
loan. Since Bard is affiliated with Columbia University, the cooperation of the Columbia Library is given generously. But often help will be received also from other libraries. The best example of liberality and understanding is offered by New York State Library. When one of the ablest Bard students decided to write his Senior Project on the history of $\boldsymbol{M c}$ Clure's Magazine, the State Library immediately agreed, in this exceptional case, to send to Bard the fifty-odd volumes that were needed. Sometimes, however, the task of getting the literature for the senior projects together becomes too heavy for the Bard Library, and the students are advised to do research in the metropolitan scholarly libraries. That in itself will be a useful experience for students who intend to go into graduate or professional schools. On the whole, the Senior Project brings about the crowning effort of the library to help in realizing the educational ideals of the college.

I have tried to describe here some phases of the work done in the libraries of the three Eastern progressive colleges in general, and experiments at Bard in particular. I am fully aware not only of our achievements, but also of our shortcomings and of the fact that some of the methods we use cannot be employed very easily in large institutions. But whatever faults there may be, these three libraries seem to be moving in the right direction. To quote once more from Branscomb: "If funds are limited and staffs are inadequate, it may be necessary to be less correct along formal lines in order to take an active part in the shift of the teaching program from reliance on formal instruction towards a greater faith in individual study." The libraries at Bard, Bennington, and Sarah Lawrence have taken this active part!

\section{The Task of the College Library}

\section{(Continued from page 4I)}

ers, methods, techniques, and processes whose only virtue is that they are so general in their character and so all-inclusive in their results that some little bit of usefulness is bound to be in them. If you shoot at a target with a shotgun, you are almost bound to hit it, and one of the shots may find the bull's-eye. But many of the shots will be wasted. A rifle with a sure aim is much more efficient.

The task of the college library, it seems to me, is to become a college library-not just a library in a college. The task of the college library is to find out; first, what it is for and for whom it exists and what its patrons need, not only in books, but in service; and then to devise ways to give these things. The ways may not be orthodox. There is little reason to suppose that they will be. The classification system may not be like any other on earth; the subject catalog may look very strange to a teacher of cataloging. But there is no essential virtue in orthodoxy when it is a question of service. The only valuable consistency is one that grows out of need, not one that grows out of practice. The college library is a highly specialized institution, giving a very special service for a special purpose to a special group. It will be a wonder indeed if the best means and methods for doing this do not turn out to be highly specialized as well. 